\title{
SANKSI PIDANA TERHADAP PELAKU TINDAK PIDANA SANTET
}

\author{
Rachmad Alif Al Buchori Ali, I Made Sepud, I Made Minggu Widyantara \\ Fakultas Hukum, Universitas Warmadewa, Denpasar-Bali, Indonesia \\ alifal587@gmail.com, sepudmade@gmail.com, mademinggu21@gmail.com
}

\begin{abstract}
Abstrak
Latar belakang filosofi santet dapat digolongkan menjadi tindak pidana dikarenakan santet diakui dan dipercaya keberadaannya di masyarakat, dan menimbulkan keresahan, namun tidak dapat dicegah dan diberantas melalui hukum karena kesulitan dalam hal pembuktiannya. Maka dalam hal ini diperlukan sanksi pidana bagi para pelaku santet. Tujuan penelitian ini untuk menganalisa sanksi pidana terhadap pelaku tindak pidana santet. Metode yang digunakan dalam penelitian ini yaitu normative dengan pendekatan perundang-undangan. Sumber data yang digunakan yaitu sumber data primer, sekunder, tersier yang diperoleh dari pencatatan dan pengutipan bahan hukum yang relevan. Hasil penelitian mengungkapkan bahwa pertanggungjawaban terhadap pelaku santet memang tidak tertulis atau tercantum dalam Kitab Undang-Undang Hukum Pidana (KUHP) yang berlaku saat ini. Tetapi lain halnya dalam Rancangan Kitab Undang-Undang Hukum Pidana (RKUHP), pelaku santet kini dapat dijadikan suatu tindak pidana walaupun tidak secara spesifik mencantumkan kata santet di dalam RKUHP. Rumusan tindak pidana dalam pasal 293 RKUHP semakin jelas bahwasannya pelaku santet yang memiliki unsur-unsur sebagaimana dimaksud dapat dikenakan hukuman penjara maksimal 5 tahun dan denda kategori IV.
\end{abstract}

Kata Kunci: Hukum, Santet, Tindak Pidana

\section{Abstract}

The philosophical background of witchcraft can be classified as a criminal act because witchcraft is recognized and believed to exist in the community, and causes unrest, but cannot be prevented and eradicated through law because of difficulties in proving it. So in this case, criminal sanctions are needed for the perpetrators of witchcraft. The purpose of this study is to analyze the criminal sanctions against the perpetrators of the crime of witchcraft. The method used in this research is normative with a statutory approach. The data sources used are primary, secondary, tertiary data sources obtained from recording and quoting relevant legal materials. The results of the study reveal that accountability for perpetrators of witchcraft is not written or listed in the current Criminal Code $(K U H P)$. But it is different in the Draft Criminal Code (RKUHP), perpetrators of witchcraft can now be made a criminal act even though it does not specifically include the word witchcraft in the RKUHP. The formulation of the crime in Article 293 of the RKUHP is increasingly clear that perpetrators of witchcraft possessing the elements referred to may be subject to a maximum imprisonment of 5 years and a category IV fine.

Keywords: Law, Witchcraft, Crime

\section{PENDAHULUAN}

Santet dapat digolongkan menjadi tindak pidana adalah karena santet diakui dan dipercaya keberadaannya di masyarakat, dan menimbulkan keresahan, namun tidak dapat dicegah dan diberantas melalui hukum karena kesulitan dalam hal pembuktiannya. Dengan alasan tersebut maka perlu dibentuk tindak pidana baru mengenai santet yang sifatnya mencegah agar perbuatan tersebut tidak terjadi.

Masalah kriminalisasi ini sangat erat kaitannya dengan criminal policy. Criminal policy adalah usaha yang rasional baik dari masyarakat/pemerintah untuk menanggulangi tindak pidana baik menggunakan sarana penal maupun non penal. Seiring berkembangnya zaman, pembaharuan peraturan hukum pidana memang perlu dilakukan sebagai kebijakan hukum pidana yang dapat disebut pula sebagai politik hukum pidana. 
Di Indonesia, sihir dikenal dengan bermacam-macam istilah yaitu seperti santet, teluh, gunaguna dan sebagainya. Indonesia sendiri belum punya payung hukum mengenai sihir ini. Karenanya bila ada orang yang diduga pelaku santet tidak bisa dijerat dengan hukum, akibatnya masyarakat yang menjadi korban santet sering main hakim sendiri bahkan orang yang diduga dukun santet sering dibunuh warga tanpa pembuktian.

Pakar hukum pidana UI Prof Dr. Ronny Nitibaskara mengatakan penerapan pasal santet bisa melindungi orang-orang yang difitnah melakukan santet. Karena dengan adanya itu maka mereka yang difitnah melakukan santet tidak bisa di main hakim sendiri. Tetapi pakar hukum pidana UI Prof Dr. Ronny Nitibaskara yang dilibatkan dalam pembuatan Rancangan KUHP ini mengaku bahwa pasal santet tersebut ada sisi negatifnya. Menurutnya, draft pasal 293 Rancangan KUHP ini tidak disusun dengan delik materiil, karena adanya kendala pembuktian. Yang dipidana bukan pembunuhan terselubung oleh tukang santet, melainkan perbuatan mereka yang mengganggu ketertiban umum.

Banyak pendapat yang mendukung Undang-undang ini walau banyak juga yang menentang. Yang mendukung beralasan bahwa korban sihir atau santet di Indonesia sangat banyak dan mereka sangat menderita dan kadang sulit disembuhkan dan akhirnya meninggal tanpa memperoleh keadilan. Sedang untuk menjawab permasalahan tersebut perlu diadakannya penelitian atau pengkajian lebih mendalam mengenai hukuman pelaku santet.

Menurut (Wicaksana et al., 2020) kebijakan hukum pidana terhadap tindak pidana santet yang diatur dalam konsep Kitab Undang-Undang Hukum Pidana (KUHP) bukan delik santet namun berhubungan dengan masalah santet (kekuatan gaib dan supranatural), khususnya yang berkaitan dengan penawaran bantuan jasa atau sarana dari orang yang mengaku memiliki keahlian supranatural (dukun atau paranormal) untuk melakukan suatu kejahatan atau tindak pidana. Lebih lanjut, ketentuan pidana mengenai santet telah dikonsepkan dalam Rancangan KUHP dari tahun 1993 hingga tahun 2019 dengan mengalami beberapa perubahan (Putra \& Wirasila, 2021). Sedangkan menurut (M \& Irfan, 2020) masih banyak pro dan kontra mengenai usulan rancangan Undang-undang mengenai sanksi hukum dalam pasal 293 (dulu Pasal 292 RUU KUHP tahun 2004) yang mengatur penggunaan Ilmu hitam, terutama dalam hal pembuktiannya.

Berdasarkan pembahasan diatas, tujuan penelitian ini untuk menganalisa sanksi pidana terhadap pelaku tindak pidana santet.

\section{METODE PENELITIAN}

Jenis penelitian yang digunakan adalah normatif. Penelitian normatif adalah pemecahan masalah berdasarkan literatur-literatur dan peraturan perundang-undangan yang berkaitan dengan permasalahan dalam penelitian ini berdasarkan adanya kesenjangan norma atau asas hukum. Dalam penelitian ini, penulis menggunakan sumber data-data yang berupa bahan hukum terdiri dari bahan hukum primer, bahan hukum sekunder, bahan hukum tersier. Teknik pengumpulan bahan hukum tahap pertama adalah mencari bahan hukum yang sesuai dengan topik atau tema penelitian yang akan dilakukan, setelah semua bahan hukum yang diperlukan dalam menulis penelitian ini baik bahan hukum primer dan bahan hukum sekunder diperoleh dan terkumpul. Tahapan selanjutnya adalah Setelah semua bahan hukum diperoleh maka tahap selanjutnya adalah mengelompokan bahan hukum sesuai dengan kebutuhan penelitian dan setelah dikelompokkan maka dilakukan analisis terkait isi dari bahan hukum dan juga mengutip dan mencatat teori-teori ataupun pendapat-pendapat hukum yang dianggap perlu untuk menganalisis isu-isu yang dibahas dalam penelitian ini.

\section{HASIL DAN PEMBAHASAN}

\section{Sanksi Pidana Terhadap Pelaku Tindak Pidana Santet}

Istilah pidana diartikan sebagai sanksi pidana, selain itu juga diartikan dengan istilah-istilah lain yaitu hukuman, penghukuman, pemidanaan, penjatuhan hukuman, pemberian pidana dan hukuman pidana. Sanksi pidana adalah suatu hukuman sebab akibat, sebab adalah kasusnya dan akibat adalah hukumnya, orang yang terkena akibat akan memperoleh sanksi baik masuk penjara ataupun terkena hukuman lain dari pihak berwajib. Sanksi pidana merupakan suatu jenis sanksi yang bersifat nestapa yang diancamkan atau dikenakan terhadap perbuatan atau pelaku perbuatan pidana atau tindak pidana yang dapat mengganggu atau membahayakan kepentingan hukum. Sanksi pidana pada dasarnya 
merupakan suatu penjamin untuk merehabilitasi perilaku dari pelaku kejahatan tersebut, namun tidak jarang bahwa sanksi pidana diciptakan sebagai suatu ancaman dari kebebasan manusia itu sendiri.

Sanksi pidana merupakan jenis sanksi yang paling banyak digunakan di dalam menjatuhkan hukuman terhadap seseorang yang dinyatakan bersalah melakukan perbuatan pidana. Sanksi tindakan merupakan jenis yang lebih banyak tersebar di luar KUHP, walaupun dalam KUHP sendiri juga bentuk-bentuknya, yaitu berupa perawatan di rumah sakit dan dikembalikan pada orang tuanya atau walinya bagi orang yang tidak mampu bertanggung jawab dan anak yang masih di bawah umur.

Dalam Black's Law Dictionary Henry Campbell Black Memberikan pengertian sanksi pidana sebagai punishment attached to conviction at crimes such fines, probation and sentences (suatu pidana yang dijatuhkan untuk menghukum suatu penjahat (kejahatan) seperti dengan pidana denda, pidana pengawasan dan pidana penjara). Berdasarkan deskripsi pengertian sanksi pidana di atas dapat disimpulkan, bahwa pada dasarnya sanksi pidana merupakan suatu pengenaan suatu derita kepada seseorang yang dinyatakan bersalah melakukan suatu kejahatan (perbuatan pidana) melalui suatu rangkaian proses peradilan oleh kekuasaan (hukum) yang secara khusus diberikan untuk hal itu, yang dengan pengenaan sanksi pidana tersebut diharapkan orang tidak melakukan tindak pidana lagi.

Berkaitan dengan macam-macam sanksi dalam hukum pidana itu dapat dilihat dalam pasal 10 Kitab Undang-Undang Hukum Pidana. Pasal 10 KUHP menentukan, bahwa pidana terdiri dari a. Pidana Mati

Hukum pidana tidak pernah melarang orang mati, akan tetapi akan melarang orang yang menimbulkan kematian, karena perbuatannya. Keberadaan pidana mati (death penalty) dalam hukum pidana (KUHP), merupakan sanksi yang paling tertinggi apabila dibandingkan dengan sanksi pidana lainnya. Dilihat dari rumusan-rumusan perbuatan di dalam KUHP, memperlihatkan bahwa ancaman pidana mati ditujukan atau dimaksudkan hanya terhadap perbuatan-perbuatan yang sangat serius dan berat. Pidana mati merupakan pidana yang paling keras dalam sistem pemidanaan. Sungguhpun demikian, pidana mati paling banyak dimuat dalam hukum pidana di banyak Negara dengan cara eksekusi dengan berbagai bentuk mulai dari pancung, digantung, disetrum listrik, disuntik hingga ditembak mati.

b. Pidana Penjara

Pidana penjara merupakan pidana pokok yang berwujud pengurangan atau perampasan kemerdekaan seseorang. Namun demikian, tujuan pidana penjara itu tidak hanya memberikan pembalasan terhadap perbuatan yang dilakukan dengan memberikan penderitaan kepada terpidana karena telah dirampas atau dihilangkan kemerdekaan bergeraknya, disamping itu juga mempunyai tujuan lain yaitu untuk membina dan membimbing terpidana agar dapat kembali menjadi anggota masyarakat yang baik dan berguna bagi masyarakat, bangsa dan Negara.

c. Pidana Kurungan

Pidana kurungan adalah bentuk-bentuk dari hukuman perampasan kemerdekaan bagi si terhukum yaitu pemisahan si terhukum dari pergaulanhidup masyarakat ramai dalam waktu tertentu dimana sifatnya sama dengan hukuman penjara yaitu perampasan kemerdekaan orang.

Terhadap pidana kurungan ini yang dianggap oleh membentuk undang-undang lebih ringan dari pidana penjara dan ini sekaligus merupakan perbedaan antara kedua pidana itu, ialah

1. Menurut pasal 12 ayat 2 KUHP lamanya hukuman penjara adalah sekurang- kurangnya (minimum) satu hari dan selama lamanya lima belas tahun berturut-turut. Maksimum 15 tahun dilampaui dalam hal gabungan tindak pidana, recidive, atau dalam hal berlakunya pasal 52 KUHP (ayat 3 dari Pasal 12).

2. Menurut pasal 19 ayat 2 KUHP, kepada seseorang hukuman kurungan diberi pekerjaan lebih ringan dari orang yang dijatuhi pidana penjara.

3. Menurut pasal 21 KUHP, hukuman kurungan harus dijalani dalam daerah Provinsi tempat si terhukum berdiam.

4. Menurut pasal 23 KUHP, orang yang dihukum dengan kurungan boleh memperbaiki nasibnya dengan biaya sendiri menurut peraturan yang ditetapkan dalam undang-undang.

d. Pidana Denda

Pidana denda adalah jenis pidana yang dikenal secara luas di dunia, dan bahkan di Indonesia. Pidana ini diketahui sejak zaman Majapahit dikenal sebagai pidana ganti kerugian. Menurut Andi Hamzah, pidana denda merupakan bentuk pidana tertua, lebih tua daripada pidana penjara, mungkin setua 
pidana mati. Dalam praktek hukum selama ini, pidana denda jarang sekali dijatuhkan. Hakim selalu menjatuhkan pidana kurungan atau penjara jika pidana denda itu diancamkan sebagai alternatif saja dalam rumusan tindak pidana yang bersangkutan, kecuali apabila tindak pidana itu memang hanya diancamkan dengan pidana denda saja, yang tidak memungkinkan hakim menjatuhkan pidana lain selain denda.

e. Pidana Tutupan

Dasar hukum diformulasikannya pidana tutupan ini dalam KUHP terdapat di dalam Undang-Undang RI 1946 No.20, berita Republik Tahun II No.24. Dalam ketentuan Pasal 2 ayat (1) dinyatakan bahwa dalam mengadili orang yang melakukan kejahatan yang diancam pidana penjara, karena terdorong oleh maksud yang patut dihormati, Hakim boleh menjatuhkan pidana tutupan. Pidana ini tidak boleh dijatuhkan bila perbuatan itu atau akibatnya sedemikian rupa, sehingga Hakim menimbang pidana penjara lebih pada tempatnya. Tempat dan cara menjalankan pidana ini diatur tersendiri dalam PP 1948 No.8. Dalam peraturan ini narapidana diperlukan jauh lebih baik dari pada pidana penjara, antara lain uang pokok, pakaian sendiri, dan sebagainya. Pengaturan terkait santet ini memang tak jarang terjadi kesalahpahaman di masyarakat, seakan-akan yang diatur dalam RUU KUHP adalah perbuatan menyantet, menenun, menyihir orang, seperti pertanyaan beberapa orang di awal tulisan ini. Kesalahpahaman ini terjadi tidak hanya di kalangan awam hukum namun juga pakar hukum. Para pakar hukum ini menyangka bahwa yang ingin diatur dalam RUU KUHP adalah perbuatan/tindakan menyantetnya.

Pengaturan RUU KUHP Pasal 293 berbunyi

1. Setiap orang yang menyatakan dirinya mempunyai kekuatan gaib, memberitahukan, menimbulkan harapan, menawarkan atau memberikan bantuan jasa kepada orang lain bahwa karena perbuatannya dapat menimbulkan penyakit, kematian, penderitaan mental atau fisik seseorang, dipidana dengan pidana penjara paling lama 5 (lima) tahun atau pidana denda paling banyak Kategori IV.

2. Jika pembuat tindak pidana sebagaimana dimaksud pada ayat (1) melakukan perbuatan tersebut untuk mencari keuntungan atau menjadikan sebagai mata pencaharian atau kebiasaan, pidananya dapat ditambah dengan 1/3 (satu pertiga).

Dari rumusan diatas terlihat bahwa yang diatur pada dasarnya bukan kegiatan menyantet itu sendiri, namun mengaku-ngaku, menawarkan jasa dst seakan-akan ia bisa menyantet orang yang dapat menimbulkan celaka. Pointnya bukan pada apakah ia memang bisa menyantet atau tidak atau bahkan ia telah menyantet atau tidak, namun cukup pada mengaku-ngaku, menawarkan jasa santet itu sendiri. Untuk bisa memahami maksud utama aturan ini kita harus memahami juga letak pasal tersebut dalam RUU KUHP. Dalam RUU KUHP Pasal 293 ini terletak di Bab V Tindak Pidana Terhadap Ketertiban Umum, Bagian Kedua Penghasutan dan Penawaran Tindak Pidana, Paragraf Kedua tentang Penawaran Tindak Pidana. Pasal pertama dari paragraf kedua ini, yaitu pasal 291 berbunyi

Setiap orang yang di muka umum dengan lisan atau tulisan menawarkan untuk memberi keterangan, kesempatan, atau sarana untuk melakukan tindak pidana, dipidana dengan pidana penjara paling lama 1 (satu) tahun atau pidana denda paling banyak Kategori II. Dengan judul paragraf serta pasal 291 di atas terlihat bahwa yang ingin diatur adalah kegiatan menawarkan -nya, bukan kegiatan santet itu sendiri. Kalau memang pembuat RUU KUHP ingin mengatur santet maka tentunya pasal ini tidak diletakkan pada Bab V, Bagian Kedua dan Paragraf Ketiga ini, namun pada Bab yang mengatur tentang Pembunuhan atau setidaknya penganiayaan.

Secara konkritnya gambaran perbuatan menawarkan jasa santet ini serupa dengan orang yang menawarkan jasa pembunuhan (pembunuh bayaran). Bukan apakah si pembunuh bayaran ini sudah membunuh orang atau tidak, karena kalau ya, itu akan menjadi delik tersendiri, delik pembunuhan berencana atau pembunuhan. Namun ketika ia sudah -katakanlah- mengiklankan diri Menyediakan jasa Pembunuhan, Kualitas Terjamin. 10 Pelanggan Pertama Akan Mendapatkan Diskon 25\% (Senin harga Naik) misalnya, maka tindakan itu sendiri sudah merupakan tindak pidana. Jadi misalnya ada yang mengaku-ngaku sebagai dukun santet, bisa menyantet orang, maka perbuatan tersebut, terlepas apakah benar/tidak terdakwa bisa menyantet, sudah melanggar Pasal 293 di atas. Cara pembuktianya cukup sederhana yaitu bukan santetnya yang coba dibuktikan, namun apakah benar terdakwa pernah mengaku-ngaku atau menawarkan diri untuk menyantet orang atau tidak. Kalau penawaran tersebut dilakukan secara tertulis (memasang iklan) berarti iklan tersebut adalah barang buktinya. Kemudian 
mencari alat bukti yang dapat menunjukkan bahwa iklan tersebut memang dibuat oleh tersangka/terdakwa. Kalau ternyata terdakwa tidak pernah beriklan, tapi hanya lisan, yang dicari adalah saksi-saksi.

\section{SIMPULAN DAN SARAN}

\section{Simpulan}

Terkait tindak pidana santet dalam hukum pidana, dalam pembahasan akan menggunakan asas legalitas sebagai bagian tinjauanya atau pasal yang berkaitan dengan tindak pidana santet yang memiliki unsur dan kesamaan delik. Yang akan dicegah/diberantas adalah profesi atau pekerjaan tukang santet yang memberikan bantuan kepada seseorang untuk menimbulkan kematian atau mencelakakan/menceritakan orang lain. Dengan perkataan lain, yang akan dikriminalisasikan adalah perbuatan menawarkan/memberikan jasa dengan ilmu santet untuk membunuh atau mencelakakan/menceritakan orang lain. Adapun Sanksi pidana pelaku santet tidak diatur didalam KUHP tetapi di Rancangan KUHP. Pelaku santet kini dapat dijadikan suatu tindak pidana walaupun tidak secara spesifik mencantumkan kata santet di dalam RKUHP.

\section{Saran}

Bagi Pemerintah perlu melakukan pembaharuan hukum pidana khususnya terhadap tindak pidana santet harus dapat segera sahkan, karena dengan masih adanya santet dikhawatirkan akan ada korban santet selanjutnya karena hukum pidana belum bisa untuk menjeratnya mengingat KUHP yang kita adopsi dari warisan Kolonial Belanda tidak mengatur masalah tindak pidana santet. Bagi Aparat penegak hukum perlu mengingat dan menetapkan bahwa hukum untuk bisa menjerat santet dengan pasal yang relevan serta dapat digunakan secara maksimal maka perlu ketegasan dari pasal tersebut, artinya tidak ada penafsiran ganda sehingga tidak timbul kebingungan apa sebenarnya yang bisa di jerat dengan pasal tersebut. Dan perlunya dilakukan sosialisasi di kalangan masyarakat yang sifat nya kontinuitas supaya tidak menimbulkan kesalahpahaman.

\section{DAFTAR PUSTAKA}

Arief, B. N. (2004). Sistem Pemidanaan dalam Ketentuan Umum Buku I RUU KUHP. Kencana, Yogyakarta.

Baharudin, E. (2007). Perlunya Pengesahan Pasal di dalam RUU KUHP Mengenai Santet (Pro dan Kontra Seputar Isu Santet di Indonesia). Lex Jurnalica, 4(2), 101-107.

Hamzah, A. (2005). Asas-Asas Hukum Pidana. PT. Yarsif Watampone, Jakarta.

M, M., \& Irfan. (2020). Sanksi Hukum Terhadap Santet Dalam Rancangan Undang-Undang KUHP (RUU KUHP) dan Hukum Islam. Shautuna, 1(2), 10-20.

Prasetyo, T., \& Barkatullah, A. H. (2012). Politik Hukum Pidana (Kajian Kebijakan Kriminalisasi dan Dekriminalisasi). Yogyakarta Pustaka Pelajar. Yogyakarta.

Putra, I. G. A. G. A., \& Wirasila, A. A. N. (2021). Tinjauan Yuridis Terhadap Delik Santet Dalam Perspektif Pembaharuan Hukum Pidana di Indonesia. Jurnal Kertha Negara, 9(2), 73-82.

Soekanto, S., \& Mamudji, S. (2004). Penelitian Hukum Normatif Suatu Tinjauan Singkat. PT. Raja Grafindo Persada, Jakarta.

Sudarto. (1981). Hukum dan Hukum Pidana. Alumni, Bandung.

Sudarto. (1986). Kapita Selekta Hukum Pidana, dan Hukum Pidana. Alumni Bandung.

Suharto, R. M. (2002). Hukum Pidana Materiil Unsur-unsur Obyektif Sebagai Dasar Dakwaan. Sinar Grafika, Jakarta.

Sulistia, T., \& Zurnetti, A. (2011). Hukum Pidana Horizon Pasca Reformasi. Rajawali Pers, Jakarta.

Wicaksana, I. P. S., Putra, Yuliartini, N. P. R., \& Mangku, D. G. S. (2020). Kebijakan Hukum Tentang Pengaturan Santet Dalam Hukum Pidana Indonesia. Jurnal Komunitas Yustisia, 3(1), 411-419.

Pasal Santet Dalam Naskah Revisi UU KUHP' di Gedung DPR Lantai 17, Jalan Gatot Subroto, Jakarta. (n.d.). Diakses Pada, Selasa (2/4/2020). www.detiknews.com 